Article

\title{
Novel Potent Hypoglycemic Compounds from Euonymus laxiflorus Champ. and Their Effect on Reducing Plasma Glucose in an ICR Mouse Model
}

\author{
Van Bon Nguyen ${ }^{1,2, *(\mathbb{D})}$, San-Lang Wang $3,4, * \mathbb{C}$, Thi Hanh Nguyen ${ }^{2}$, Minh Trung Nguyen ${ }^{2}{ }^{(\mathbb{D}}$, \\ Chien Thang Doan ${ }^{2,3} \mathbb{B}^{\mathbb{D}}$, Thi Ngoc Tran ${ }^{2,3}$, Zhi-Hu Lin ${ }^{5}$, Quang Vinh Nguyen ${ }^{6}$, \\ Yao-Haur Kuo ${ }^{5,7, *}$ and Anh Dzung Nguyen ${ }^{6, *}$ \\ 1 Institute of Research and Development, Duy Tan University, Da Nang 550000, Vietnam \\ 2 Department of Science and Technology, Tay Nguyen University, Buon Ma Thuot 630000, Vietnam; \\ nguyenhanh2208.tn@gmail.com (T.H.N.); nguyenminhtrung2389@gmail.com (M.T.N.); \\ doanthng@gmail.com (C.T.D.); tranngoctnu@gmail.com (T.N.T.) \\ 3 Department of Chemistry, Tamkang University, New Taipei City 25137, Taiwan \\ 4 Life Science Development Center, Tamkang University, New Taipei City 25137, Taiwan \\ 5 Division of Chinese Materia Medica Development, National Research Institute of Chinese Medicine, \\ Taipei 11221, Taiwan; tiger77749@gmail.com \\ 6 Institute of Biotechnology and Environment, Tay Nguyen University, Buon Ma Thuot 630000, Vietnam; \\ vinh12b@yahoo.com \\ 7 Graduate Institute of Integrated Medicine, College of Chinese Medicine, China Medical University, \\ Taichung 40402, Taiwan \\ * Correspondence: bondhtn@gmail.com (V.B.N.); sabulo@mail.tku.edu.tw (S.-L.W.); \\ kuoyh@nricm.edu.tw (Y.-H.K.); nadzungtaynguyenuni@yahoo.com.vn (A.D.N.); \\ Tel.: +886-2-2621-5656 (S.-L.W.); Fax: +886-2-2620-9924 (S.-L.W.)
}

Received: 5 June 2018; Accepted: 1 August 2018; Published: 2 August 2018

Abstract: $\alpha$-Glucosidase inhibitors (aGIs) have been used as an effective therapy for type-2 diabetes, which remains a global health issue. The aim of this study was to achieve bioactivity-guided isolation, identification and evaluation of hypoglycemic compounds from Euonymus laxiflorus Champ. trunk bark (ELCTB). Eleven active compounds were isolated and identified as walterolactone A/B $\beta$-D-pyranoglucoside (1), 1- $\beta$-D-glucopyranosyloxy-3,5-dimethoxy-4hydroxybenzene (9), (-)-gallocatechin (10), schweinfurthinol 9-O- $\beta$-D-pyranoglucoside (11), 1-O(3-methyl)-butenoyl-myo-inositol (12), leonuriside (14), (+)-catechin (19), methyl galloate (20), (-)-catechin (23), and condensed tannins (5 and 18). Of these 11, novel 4 compounds $(\mathbf{1}, \mathbf{1 1}, \mathbf{1 2}$, and $\mathbf{1 4}$ ) were found as new $\alpha$-glucosidase inhibitors. Notably, in vitro results indicated that compounds $1, \mathbf{5}, \mathbf{1 0 - 1 2}, \mathbf{1 8}$, and 19 showed potent activity $\left(\mathrm{IC}_{50}=0.076-31 \mu \mathrm{g} / \mathrm{mL}\right.$ ), and their activities were at a higher level than that of acarbose, a commercial inhibitor ( $\mathrm{IC}_{50}=1345 \mu \mathrm{g} / \mathrm{mL}$ ). In animal tests, the major inhibitor, condensed tannin (18), demonstrated significant reduction of plasma glucose in mice with no symptoms of diarrhea at the dose of $100 \mathrm{mg} / \mathrm{kg}$ bw. The results suggest that Euonymus laxiflorus Champ. is a rich source of bioactive compounds for development as health food or drugs with potent hypoglycemic effect. The results of this study also enriched the current novel biological activities of constituents from Euonymus laxiflorus species.

Keywords: Euonymus laxiflorus Champ.; diabetes; $\alpha$-glucosidase inhibitors; plasma glucose; condensed tannins; natural products

\section{Introduction}

Natural bioactive products are of great interest due to their beneficial use as health foods or drugs to manage significant numbers of diseases including type-2 diabetes (T2D), a serious current global 
health issue [1,2]. Several therapies, including the use of $\alpha$-glucosidase inhibitors (aGIs), have been applied for T2D management [3]. To date, some commercial aGIs have become available for T2D treatment, such as acarbose, miglitol, and voglibose. However, the use of these commercial drugs was reported to cause several side effects, such as diarrhea, flatulence, and abdominal discomfort [4]. Thus, the investigation of natural sources of aGIs for safe use is required.

aGIs could be obtained from various sources, such as herbal extracts [4-7], biosynthesis via microbial fermentation [2,8-12], or chemical synthesis [13,14]. Herbals were suggested as rich natural sources of aGIs, which may be useful in providing therapy for T2D [4,5]; as such, the bioassay-guided isolation and identification of active aGIs from potent antidiabetic herbals have proven valuable in research.

Euonymus laxiflorus Champ. is distributed in some Asian countries, including China, Vietnam, Cambodia, India, and Myanmar [15]. This herbal species was evaluated as the most potent source of aGIs and $\alpha$-amylase inhibitors (aAIs) among various medicinal herbals collected in the central highlands of Vietnam in our previous studies [4,16]. The significant effect on the reduction of plasma glucose in diabetic rats of the methanolic extract of Euonymus laxiflorus Champ. trunk bark (ELCTB) was also previously recorded [17]. Recently, some compounds possessing $\alpha$-amylase inhibitory activity were isolated and identified from the methanolic extract of the trunk bark of Euonymus laxiflorus Champ. [18]; as well, several compounds showing anti-nitro oxide activity were isolated from its leaves [19]. However, no compounds showing $\alpha$-glucosidase inhibitory property were reported to be isolated and identified from this herbal species.

As part of our ongoing objective to develop Euonymus laxiflorus Champ. as a health food and drug with potent hypoglycemic function, the methanolic extract of ELCTB was conducted to isolate and identify active $\alpha$-glucosidase inhibitors. The major and most active inhibitor was also tested for its effect on reducing blood glucose in mice.

\section{Results and Discussion}

\subsection{Reclamation of Euonymus laxiflorus Champ. Extracts as a Potent Source of Natural aGIs}

The methanol extract of Euonymus laxiflorus Champ. trunk bark (ELCTB) was newly found to be the most potent source of aGIs among 26 samples of indigenous medicinal plants collected in Dak Lak Province, Vietnam [4], showing effective inhibition against various $\alpha$-glucosidases from rat $\left(\mathrm{IC}_{50}=360 \mu \mathrm{g} / \mathrm{mL}\right)$, S. cerevisiae $\left(\mathrm{IC}_{50}=1.32 \mu \mathrm{g} / \mathrm{mL}\right)$, and B. stearothermophilus $\left(\mathrm{IC}_{50}=5.15 \mu \mathrm{g} / \mathrm{mL}\right)$.

In the comparison, this herbal extract demonstrated comparable or much higher $\alpha$-glucosidase inhibitory activity compared to those of extracts from other reported herbals also collected in the central highlands of Vietnam due to its smallest $\mathrm{IC}_{50}$ values against $\alpha$-glucosidases from rat (Table 1 ).

Table 1. $\alpha$-Glucosidase inhibition by some $\mathrm{MeOH}$ extracts of medicinal plants collected in Dak Lak.

\begin{tabular}{cccc}
\hline Scientific Name of Medicinal Plants & Part Used & IC $_{\mathbf{5 0}}(\boldsymbol{\mu g} / \mathbf{m L})$ & Ref. \\
\hline Euonymus laxiflorus Champ. & Trunk bark & $360 \pm 28.9^{\mathrm{d}, \mathrm{e}}$ & Nguyen et al., 2017 [4] \\
Euonymus laxiflorus Champ. & Leaves & $670 \pm 40.4^{\mathrm{d}}$ & Nguyen et al., 2017 [4] \\
Cinnamomum cassia J. S. Presl. & Trunk bark & $1080 \pm 103.9^{\mathrm{c}}$ & Nguyen et al., 2017 [4] \\
Terminalia bellirica & Leaves & $660 \pm 63.5^{\mathrm{d}}$ & Nguyen et al., 2017 [4] \\
Terminalia bellirica & Trunk bark & $410 \pm 30.4^{\mathrm{d}, \mathrm{e}}$ & Nguyen et al., 2016 [5] \\
Terminalia corticosa & Trunk bark & $1420 \pm 20.2^{\mathrm{b}, \mathrm{c}}$ & Nguyen et al., 2016 [5] \\
Psidium littorale Raddi & Leaves & $250 \pm 10.4^{\mathrm{e}}$ & Nguyen et al., 2018 [6] \\
Dalbergia tonkinensis & Heartwood & $1720 \pm 116^{\mathrm{b}}$ & Nguyen et al., 2018 [7] \\
Dalbergia tonkinensis & Trunk bark & $2910 \pm 289^{\mathrm{a}}$ & Nguyen et al., 2018 [7] \\
Dalbergia tonkinensis & Leaves & $2780 \pm 173^{\mathrm{a}}$ & Nguyen et al., 2018 [7] \\
\hline
\end{tabular}

$\alpha$-Glucosidase from rat was used for testing; results are means \pm SD of multi tests $(n=3)$; coefficient of variation $=12.35314$; the means of $\mathrm{IC}_{50}$ values with the different letter are significantly different in comparison based on Duncan's multiple range test (alpha $=0.01)$ using SAS version 9.4, Statistical Analysis Software analysis. 
The methanol extract of this herbal also possesses significant effect on reducing plasma glucose in diabetic rats [17]. Thus, it was used for bioactivity-guided isolation of active hypoglycemic compounds via several columns, such as Diaion, Octadecylsilane, and preparative HPLC columns in the current report.

\subsection{Purification of Active aGIs from $\mathrm{MeOH}$ Extract of ELCTB}

\subsubsection{Separation, Subfractionation and Isolation of Compounds from ELCTB Extract}

The methanol extract of Euonymus laxiflorus Champ. trunk bark (ELCTB) was first separated via a Diaion column to obtain five fractions. The crude sample and its fractions were tested for their inhibition against yeast $\alpha$-glucosidase, and the results are presented in Table 2. The fractions ELCTB-2 (eluted with 40\% MeOH) and ELCTB-3 (eluted with 70\% MeOH) demonstrated the highest activity with low $\mathrm{IC}_{50}$ and great inhibition (\%) values of $2.80 \mu \mathrm{g} / \mathrm{mL}, 99 \%$, and $3.50 \mu \mathrm{g} / \mathrm{mL}, 98 \%$, respectively. Thus, they were chosen for further separation.

Table 2. $\alpha$-Glucosidase inhibitory activity of methanol extract of Euonymus laxiflorus Champ. trunk bark (ELCTB), and its fraction and subfraction separation via Diaion and ODS (Octadecylsilane) columns, respectively.

\begin{tabular}{|c|c|c|c|}
\hline \multirow{2}{*}{ Fractions/Subfractions } & \multirow{2}{*}{$\%$ Gradient of Solvent in Water } & \multicolumn{2}{|c|}{$\alpha$-Glucosidase Inhibitory Activity } \\
\hline & & $\mathrm{IC}_{50}(\mu \mathrm{g} / \mathrm{mL})$ & Inhibition (\%) * \\
\hline \multicolumn{4}{|c|}{ Separation of ELCTB via a Diaion column with $\mathrm{MeOH}$ in $\mathrm{H}_{2} \mathrm{O}$} \\
\hline ELCTB & & $7.16 \pm 0.21$ & $98 \pm 2.5$ \\
\hline ELCTB-1 & 0 & $21.75 \pm 1.32$ & $67 \pm 3.3$ \\
\hline ELCTB-2 & 40 & $2.80 \pm 0.03$ & $99 \pm 3.1$ \\
\hline ELCTB-3 & 70 & $3.50 \pm 0.12$ & $98 \pm 1.4$ \\
\hline ELCTB-4 & 100 & $18.50 \pm 1.39$ & $97 \pm 2.3$ \\
\hline ELCTB-5 & $100 \%$ EA & - & - \\
\hline \multicolumn{4}{|c|}{ Separation of ELCTB-2 via an ODS column with $\mathrm{MeOH}$ in $\mathrm{H}_{2} \mathrm{O}$} \\
\hline ELCTB-2.1 & 0 & $6.20 \pm 0.43$ & $97 \pm 3.5$ \\
\hline ELCTB-2.2 & 5 & $85.30 \pm 4.03$ & $97 \pm 2.9$ \\
\hline ELCTB-2.3 & 10 & $26.03 \pm 1.83$ & $98 \pm 1.8$ \\
\hline ELCTB-2.4 & 15 & $14.96 \pm 0.78$ & $98 \pm 3.0$ \\
\hline ELCTB-2.5 & 20 & $6.56 \pm 0.45$ & $97 \pm 2.0$ \\
\hline ELCTB-2.6 & 25 & $6.92 \pm 0.73$ & $99 \pm 1.3$ \\
\hline ELCTB-2.7 & 30 & $72.95 \pm 3.93$ & $98 \pm 1.0$ \\
\hline ELCTB-2.8 & 35 & $6.42 \pm 0.41$ & $98 \pm 2.8$ \\
\hline ELCTB-2.9 & 40 & $10.75 \pm 0.63$ & $95 \pm 3.7$ \\
\hline ELCTB-2.10 & 100 & - & - \\
\hline \multicolumn{4}{|c|}{ Separation of ELCTB-3 via an ODS column with ACN in $\mathrm{H}_{2} \mathrm{O}$} \\
\hline ELCTB-3.1 & 10 & $1.12 \pm 0.03$ & $100 \pm 2.3$ \\
\hline ELCTB-3.2 & 15 & $6.21 \pm 0.05$ & $97 \pm 2.0$ \\
\hline ELCTB-3.3 & 20 & $2.48 \pm 0.07$ & $97 \pm 2.4$ \\
\hline ELCTB-3.4 & 25 & $1.64 \pm 0.04$ & $99 \pm 3.6$ \\
\hline ELCTB-3.5 & 30 & $1.95 \pm 0.08$ & $97 \pm 2.7$ \\
\hline ELCTB-3.6 & 35 & $1.89 \pm 0.0$ & $100 \pm 2.0$ \\
\hline ELCTB-3.7 & 40 & $4.87 \pm 0.12$ & $99 \pm 3.0$ \\
\hline ELCTB-3.8 & 45 & $4.34 \pm 0.21$ & $99 \pm 3.4$ \\
\hline ELCTB-3.9 & 50 & $7.506 \pm 0.32$ & $96 \pm 3.8$ \\
\hline ELCTB-3.10 & 100 & - & - \\
\hline Acarbose & & $1239 \pm 78$ & $64 \pm 2.4$ \\
\hline
\end{tabular}

(-): no $\alpha$-glucosidase inhibition; $\left(^{*}\right)$ : the inhibition of samples and acarbose were tested at their concentration of $150 \mu \mathrm{g} / \mathrm{mL}$ and $2500 \mu \mathrm{g} / \mathrm{mL}$, respectively; EA: ethyl acetate.

Fractions ELCTB-2 and ELCTB-3 were loaded onto ODS columns and eluted with MeOH and $\mathrm{ACN}$ in $\mathrm{H}_{2} \mathrm{O}$, respectively, to obtain 10 subfractions from each fraction, and their $\alpha$-glucosidase 
inhibitory activity was tested. As shown in Table 2, subfraction ELCTB-2.1 showed good activity $\left(\mathrm{IC}_{50}=6.20 \mu \mathrm{g} / \mathrm{mL}\right.$, max inhibition $\left.=97 \%\right)$. Similarly, subfraction ELCTB-3.1 demonstrated the highest activity $\left(\mathrm{IC}_{50}=1.12 \mu \mathrm{g} / \mathrm{mL}\right.$, max inhibition $\left.=100 \%\right)$ among the 10 subfractions separated from ELCTB-3. Thus, these 2 potent subfractions were chosen for the isolation of active compounds. The other three fractions: ELCTB-2.2, ELCTB-2.3, and ELCTB-3.3 were also considered for further purification due to their good TLC separation profiles. From these five subfractions (ELCTB-2.1, ELCTB-2.2, ELCTB-2.3, ELCTB-3.1, and ELCTB-3.3), a total of 26 compounds were isolated by utilizing preparative HPLC. The purification process is summarized in Figure 1.

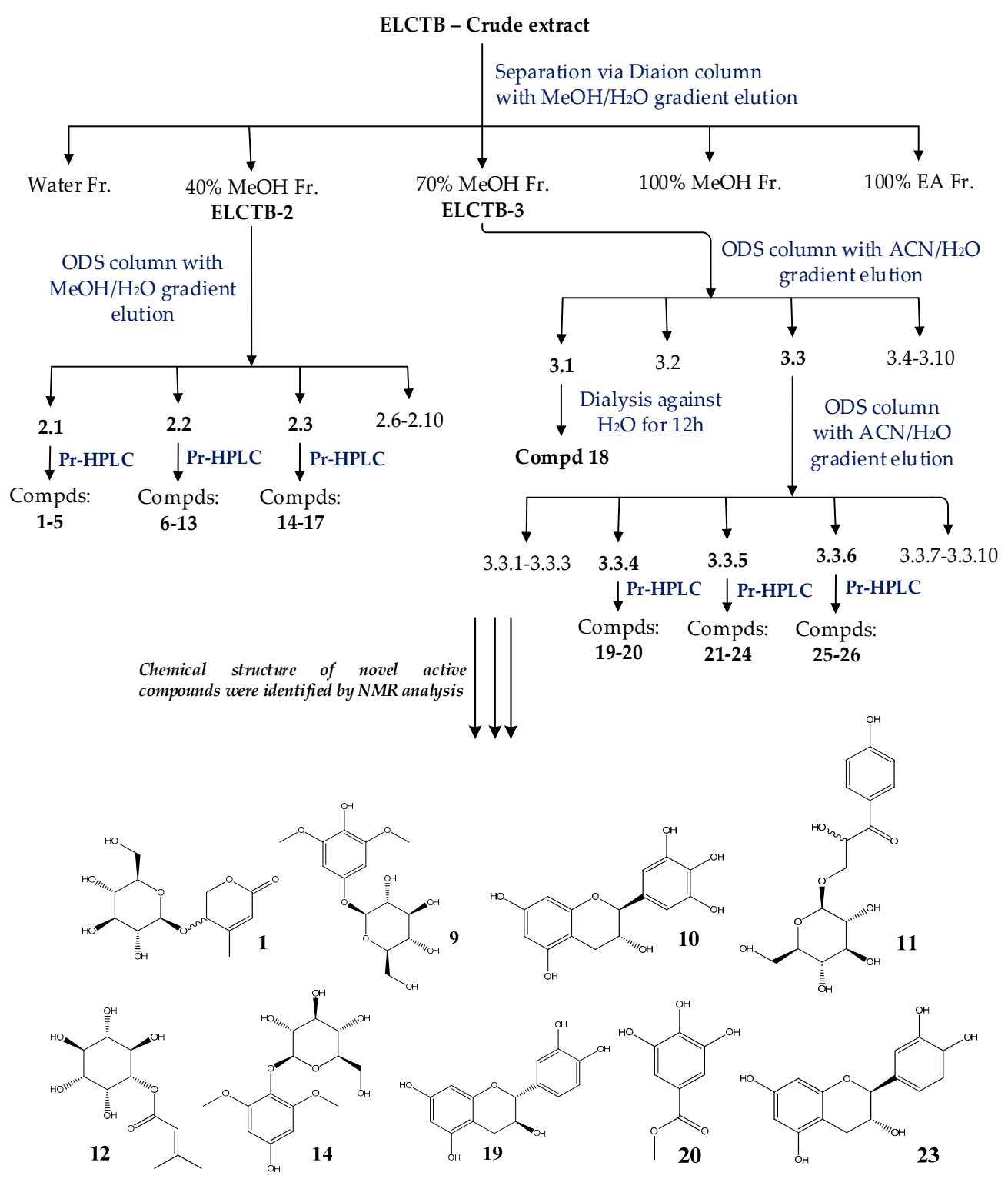

Figure 1. Flow chart on the purification and identification of active compounds from ELCTB extract. ACN: acetonitrile; ODS: octadecylsilane; Compds: compounds; Pr-HPLC: preparative high-performance liquid chromatography. (1): Walterolactone A/B $\beta$-D-pyranoglucoside; (9): 1- $\beta$-D-glucopyranosyloxy-3,5-dimethoxy-4-hydroxybenzene; (10): (-)-gallocatechin; (11): schweinfurthinol 9-O- $\beta$-D-pyranoglucoside; (12): 1-O-(3-methyl)-butenoyl-myo-inositol; (14): leonuriside; (19): (+)-catechin; (20): methyl galloate; (23): (-)-catechin. 


\subsubsection{Evaluation and Identification of Active aGIs}

The 26 isolated compounds were primarily tested for their inhibition against $\alpha$-glucosidase at the same concentration of $250 \mu \mathrm{g} / \mathrm{mL}$; the $\alpha$-glucosidase inhibition, aGI (\%), is presented in Figure 2. Eight compounds: 1, 5, 10, 11, 12, 14, 18, and 19, demonstrated potent activity $(90-100 \%$, ranked at level A), and three compounds: 9, 20, and 23, showed activity of 38-60\% (ranked at level B-C based on Duncan's Multiple Range Test (alpha $=0.01)$ ).

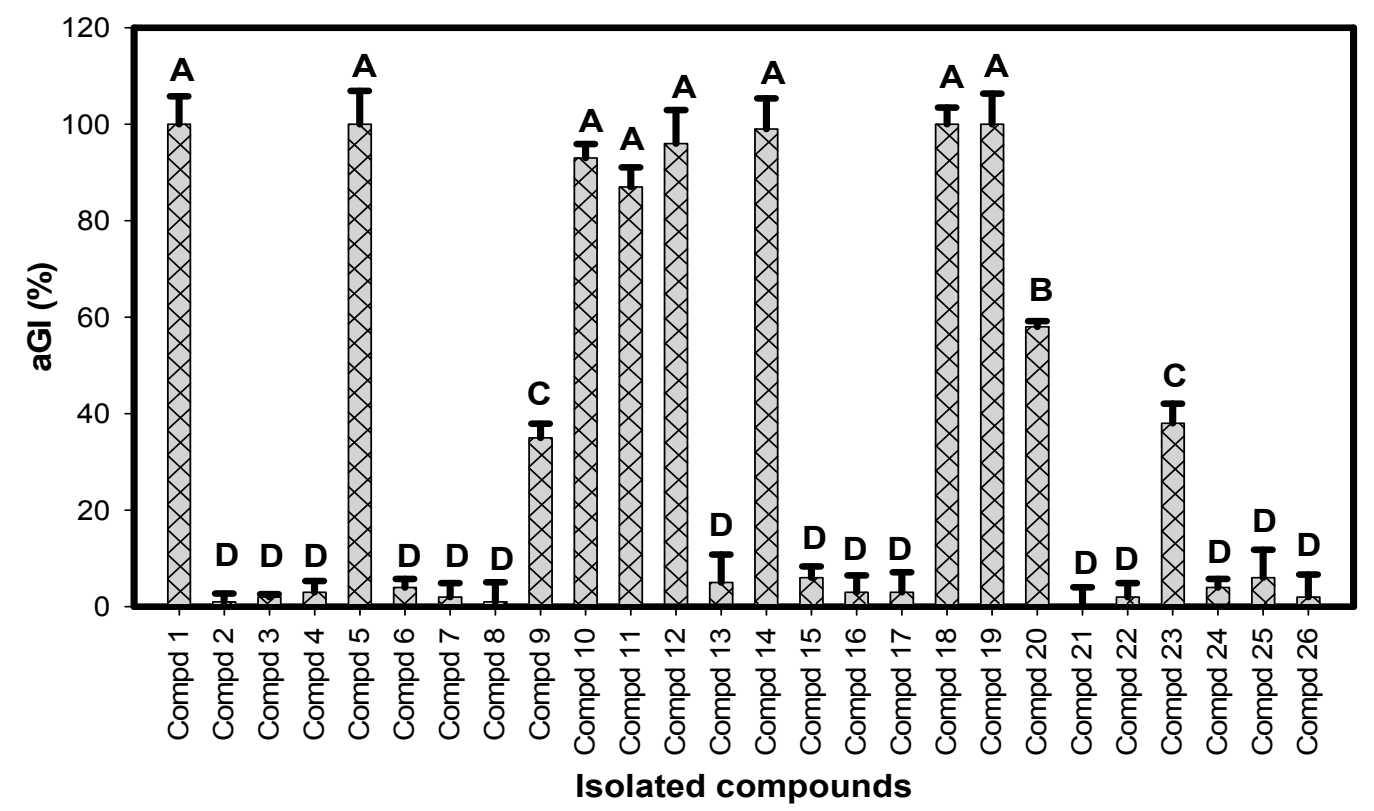

Figure 2. Evaluation of $\alpha$-glucosidase inhibition (aGI (\%)) of isolated compounds. All compounds were tested at a concentration of $250 \mu \mathrm{g} / \mathrm{mL}$. Results are means \pm SD of multi tests $(n=3)$. Coefficient of variation $(\%)=21.72221$. Mean values with the different letters are significantly different based on Duncan's Multiple Range Test (alpha $=0.01$ ).

The chemical structures of the active compounds $(\mathbf{1}, \mathbf{5}, \mathbf{9}, \mathbf{1 0}, \mathbf{1 1}, \mathbf{1 2}, \mathbf{1 4}, \mathbf{1 8}, \mathbf{1 9}, \mathbf{2 0}$, and 23) were identified via analysis of their NMR data, including ${ }^{1} \mathrm{H}-\mathrm{MNR},{ }^{13} \mathrm{C}-\mathrm{NMR}, \mathrm{COSY}, \mathrm{HSQC}$, and HMBC coupled with the comparison of those of reported compounds. These active compounds were identified as walterolactone A/B $\beta$-D-pyranoglucoside (1) [18]; 1- $\beta$-D-glucopyranosyloxy-3,5-dimethoxy-4hydroxybenzene (9) [20]; (-)-gallocatechin (10) [21]; schweinfurthinol 9-O- $\beta$-D-pyranoglucoside (11) [18]; 1-O-(3-methyl)-butenoyl-myo-inositol (12) [18]; leonuriside (14) [22,23]; (+)-catechin (19) [21]; methyl galloate (20) [24]; (-)-catechin (23) [21]; and condensed tannin (5 and 18) [18]. The NMR data of all these identified compounds are presented in the materials and methods section.

Compounds 5 \& 18 were confirmed as condensed tannins by using total phenolic determination, biological assays [25], and comparison of their ${ }^{13} \mathrm{C}-\mathrm{NMR}$ data with those of reported condensed tannins $[18,26,27]$. These 2 compounds were pre-confirmed as tannins since they contained $\geq 94 \%$ total phenolic acid and also exhibited tested biological activities, including antioxidant activity ( $\geq 96 \%), \alpha$-amylase inhibition $(100 \%)$, and protease inhibition $(\geq 95 \%)$ at their tested concentration of $1 \mathrm{mg} / \mathrm{mL}$. In addition, the ${ }^{13} \mathrm{C}-\mathrm{NMR}$ data on these compounds (materials and methods section) were similar to those of condensed tannin ELC3.1-d isolated and identified from the same herbal species [18], and also closely similar to those of other reported condensed tannins, including persimmon tannin [26], and condensed tannins from Delonix regia [27]. Thus, compounds 5 \& 18 were confirmed as condensed tannins.

Compounds 1, 11, and 12 were newly isolated and identified as new compounds from the same medicinal plant in the previous report by Nguyen et al. [18]. However, the $\alpha$-glucosidase inhibitory 
activity of these compounds was investigated for the first time in this study. They were determined as new aGIs based on the current literature review, and all their NMR spectrums, including ${ }^{1} \mathrm{H}-\mathrm{MNR}$, ${ }^{13} \mathrm{C}-\mathrm{NMR}, \mathrm{DEPT}_{135}, \mathrm{COSY}, \mathrm{HSQC}$, and HMBC were presented in the supplementary materials section (Figures S1-S21). Compound 14, leonuriside, was reported to possess several bioactive properties, including $\alpha$-amylase inhibition [18], COX-1 inhibition [24], and potent anti-NO [22]. However, the $\alpha$-glucosidase inhibition of leonuriside had not been reported before; this compound was also determined as a new aGI.

Other known phenolic compounds: 5, 9, 10, 18-20, and 23, have been reported to exhibit numerous beneficial bioactivities, including antimicrobial, cytotoxic [28], antiviral [29], antioxidant [30,31], anti-inflammatory [32], and enzyme inhibitory activities [18,20,33,34], as well as exercising a relaxation effect [35]. The results indicate that Euonymus laxiflorus Champ. is a rich potent source of hypoglycemic compounds, and possesses many other valuable biological activities.

\subsection{Comparision of $\alpha$-Glucosidase Inhibitory Activity of Identified Compounds}

To screen the most active $\alpha$-glucosidase inhibitors, all the isolated inhibitors were tested for their activity at various concentrations; the activity was then expressed as $\mathrm{IC}_{50}(\mu \mathrm{g} / \mathrm{mL})$ value. As shown in Table 3, compounds $\mathbf{1}, \mathbf{5}, \mathbf{1 4}, \mathbf{1 8}$, and 19 demonstrated the most effective inhibition due to their smallest $\mathrm{IC}_{50}$ values $(0.076-0.926 \mu \mathrm{g} / \mathrm{mL})$. These inhibitors also showed great maximum inhibition $(99-100 \%$ at $250 \mu \mathrm{g} / \mathrm{mL}$ ). Compounds 10, 11, and 12 were also found as potent inhibitors, which possessed low $\mathrm{IC}_{50}$ values $(11.9-31.6 \mu \mathrm{g} / \mathrm{mL}$ ) and high maximum inhibition (87-96\%). Compounds 9 and 23 showed weak activity $(\leq 38 \%)$. Overall, these novel inhibitors had their activity ranked sequentially based on Duncan's Multiple Range Test (alpha $=0.01$ ): $\mathbf{9} \& \mathbf{2 3} \leq$ acarbose $\leq \mathbf{2 0} \leq \mathbf{1 0}, \mathbf{1 1} \& \mathbf{1 2} \leq \mathbf{1}, \mathbf{5}, \mathbf{1 4}, \mathbf{1 8} \& \mathbf{1 9}$.

Table 3. $\alpha$-Glucosidase inhibitory activity of isolated compounds.

\begin{tabular}{|c|c|c|c|}
\hline No. & Compound & $\mathrm{IC}_{50}(\mu \mathrm{g} / \mathrm{mL})$ & Maximum Inhibition (\%) \\
\hline 1 & $\begin{array}{l}\text { Walterolactone A/B } \\
\beta \text {-D-pyranoglucoside }\end{array}$ & $0.907 \pm 0.102^{\mathrm{e}}$ & $100 \pm 5.8^{a}$ \\
\hline 5 & Condensed tannin-ELCTB-2.1.2 & $0.083 \pm 0.004^{\mathrm{e}}$ & $100 \pm 6.9^{\mathrm{a}}$ \\
\hline 9 & $\begin{array}{c}\text { 1- } \beta \text {-D-Glucopyranosyloxy-3,5-dimethoxy-4 } \\
\text {-hydroxybenzene }\end{array}$ & UD & $35 \pm 2.9^{c}$ \\
\hline 10 & $(-)-$ Gallocatechin & $11.9 \pm 1.674^{\mathrm{d}}$ & $93 \pm 2.9^{a}$ \\
\hline 11 & $\begin{array}{l}\text { Schweinfurthinol } \\
\text { 9-O- } \beta \text {-D-pyranoglucoside }\end{array}$ & $31.6 \pm 0.924^{b}$ & $87 \pm 4.0^{\mathrm{a}}$ \\
\hline 12 & 1-O-(3-Methyl)-butenoyl-myo-inositol & $27.1 \pm 1.212^{\mathrm{c}}$ & $96 \pm 6.9^{\mathrm{a}}$ \\
\hline 14 & Leonuriside & $0.926 \pm 0.043^{\mathrm{e}}$ & $99 \pm 6.4^{\mathrm{a}}$ \\
\hline 18 & Condensed tannin-ELCTB-3.1. & $0.076 \pm 0.008^{\mathrm{e}}$ & $100 \pm 6.2^{\mathrm{a}}$ \\
\hline 19 & $(+)$-Catechin & $0.113 \pm 0.008^{\mathrm{e}}$ & $100 \pm 5.9^{a}$ \\
\hline 20 & Methyl galloate & $110 \pm 1.732^{\mathrm{a}}$ & $58 \pm 1.2^{b}$ \\
\hline \multirow[t]{3}{*}{23} & $(-)$-Catechin & UD & $38 \pm 4.0^{c}$ \\
\hline & Acarbose (positive control) & $1345 \pm 89$ & $65 \pm 2.7$ \\
\hline & Coefficient of variation $(\%)$ & 6.510292 & 8.746013 \\
\hline
\end{tabular}

All compounds were tested at concentrations in the range of $0.122-7.81 \mu \mathrm{g} / \mathrm{mL}$ (compounds 1 and 14), $0.0152-0.977 \mu \mathrm{g} / \mathrm{mL}$ (compounds 5, 18, and 19), 31.25-250 $\mu \mathrm{g} / \mathrm{mL}$ (compounds 9, 20, and 23), 1.95-250 $\mu \mathrm{g} / \mathrm{mL}$ (compounds 10, 11 and 12), 156.25-2500 $\mu \mathrm{g} / \mathrm{mL}$ (acarbose), and the maximum inhibition was recorded at the compounds concentration of $7.81 \mu \mathrm{g} / \mathrm{mL}$ (compounds $\mathbf{1}$ and 14), $0.977 \mu \mathrm{g} / \mathrm{mL}$ (compounds 5, 18, and 19), $250 \mu \mathrm{g} / \mathrm{mL}$ (compounds 9, 10, 11, 12, 20, and 23), and $2500 \mu \mathrm{g} / \mathrm{mL}$ (acarbose); the means of $\mathrm{IC}_{50}$, and maximum inhibition values with the different letters in the same column are significantly different in comparison based on Duncan's multiple range test $(\mathrm{alpha}=0.01)$ using SAS version 9.4, Statistical Analysis Software. UD: unable to determine.

\subsection{The Effect of Condensed Tannin (CT) on Reducing Plasma Glucose in a Mouse Model}

Condensed tannin-ELCTB-3.1 (CT) was isolated at a large amount ( 2000 mg) and showed efficient inhibition against $\alpha$-glucosidase. Thus, this major inhibitor was conducted to test its effect on reducing plasma glucose in mice. To evaluate the effect of the samples on reducing plasma glucose in animals, sucrose and starch tolerance tests were used [11,36]. In this study, starch $(3 \mathrm{~g} / \mathrm{kg} \mathrm{bw})$ 
was chosen for the assay, since it is abundant in cereals, the daily food of people in Asian countries. Therefore, in the case that the compound (CT) showed significant effect on the reducing plasma glucose in mice, it may show potent hypoglycemic effect in humans.

Two doses of isolated CT (50 and $100 \mathrm{mg} / \mathrm{kg} \mathrm{bw}$ ) were orally administered to mice to evaluate the effect on their plasma glucose level. CT at the dose of $50 \mathrm{mg} / \mathrm{kg}$ bw showed significant reduction of plasma glucose in mice at $0.5 \mathrm{~h}$ after CT administration; thereafter, the hypoglycemic effect showed less significant difference than that of the control group (mice administered water only) (Figure 3A). On the other hand, the effect of CT on the reduction of plasma of mice at the dose of $100 \mathrm{mg} / \mathrm{kg} \mathrm{bw}$ was clearly observed from 0.5 to $2 \mathrm{~h}$ after CT administration (Figure 3B). Notably, the effect of CT at $100 \mathrm{mg} / \mathrm{kg}$ bw was comparable to that of acarbose at $50 \mathrm{mg} / \mathrm{kg}$ bw (Figure 3B), and much higher than that of acarbose at $25 \mathrm{mg} / \mathrm{kg}$ bw (Figure 3A). The mice showing symptoms of diarrhea during the tests were recorded. CT at all treated doses on mice led to no symptoms of diarrhea in mice, while mice with this illness symptom were recorded at $20 \%$ and $50 \%$ of the mice treated with acarbose doses of 25 and $50 \mathrm{mg} / \mathrm{kg}$ bw, respectively.

A

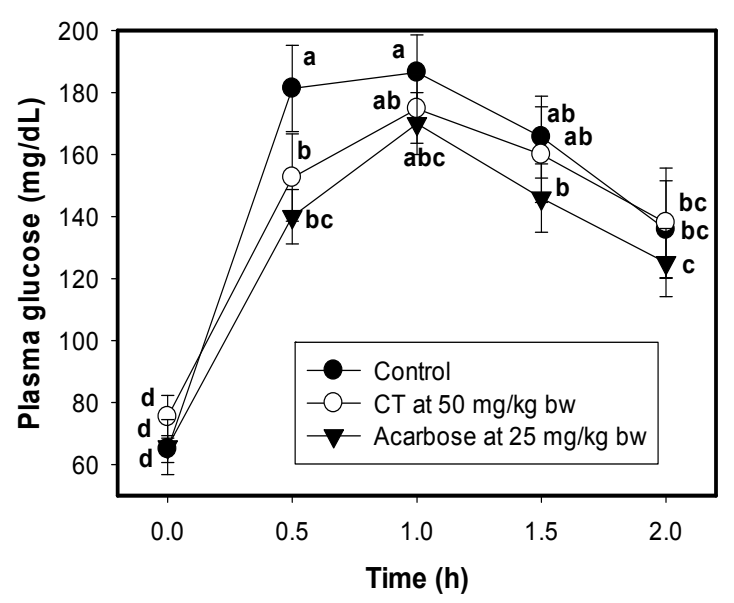

B

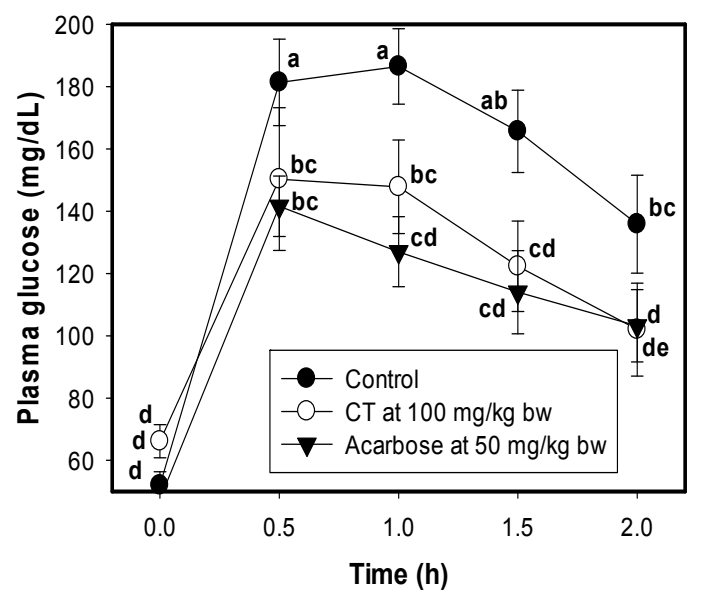

Figure 3. The effect of condensed tannin-ELCTB-3.1.1 and acarbose on reducing plasma glucose in ICR (Institute of Cancer Research) mice. Condensed tannin-ELCTB-3.1.1 and acarbose at the doses of $50 \mathrm{mg} / \mathrm{kg}$ bw and $25 \mathrm{mg} / \mathrm{kg}$ bw (A), $100 \mathrm{mg} / \mathrm{kg}$ bw and $50 \mathrm{mg} / \mathrm{kg}$ bw (B), respectively, were administered to mice $(n=8)$. Distilled water was administered to mice in the control groups $(\bullet, n=8)$. Blood of mice was sampled and measured at $0.5,1,1.5$, and $2 \mathrm{~h}$ after loading the compound or acarbose. Means of blood glucose level with the different letters in the same figure are significantly different based on Duncan's Multiple Range Test (alpha $=0.05)$. CV: coefficient of variation.

Natural products such as tea and coffee with high polyphenolic compounds content [37], were reported to show good effect on the reduction of plasma glucose in mice [38], as well as on postprandial plasma glucose in healthy humans [37]. Some herbal extracts rich in condensed tannins $[6,17,39]$ were also tested for their anti-hyperglycemic effects in diabetic rats. Psidium littorale Raddi leaf extract at the dose of $150 \mathrm{mg} / \mathrm{kg}$ bw reduced fasting plasma glucose levels in streptozotocin-induced diabetic rats [6]. The methanolic extract of Euonymus laxiflorus Champ. trunk bark (the crude sample of CT) showed significant reduction of blood glucose in diabetic rats at the dose of $200 \mathrm{mg} / \mathrm{kg}$ bw, comparable to that of acarbose at $120 \mathrm{mg} / \mathrm{kg}$ bw [17]. The pinhão coat extract, and the $A$. mearnsii tannin also demonstrated significant effectiveness in diminishing the post-prandial glycemic levels in rats at their doses of $250 \mathrm{mg} / \mathrm{kg}$ bw after starch administration [39]. In this study, Euonymus laxiflorus Champ. condensed tannins demonstrated significant effect on reducing plasma glucose at their low doses of 50, and $100 \mathrm{mg} / \mathrm{kg}$ bw. 
Condensed Tannins possess vast beneficial bioactivities, including cardio-protective, antioxidative, antitumor, antiviral, antibacterial, immune-modulatory, anti-inflammatory activities, antiobesity, antidiabetic [40,41], and hypoglycemic effects [39]. Euonymus laxiflorus Champ. condensed tannins (condensed tannin-ELCTB-3.1) were found to possess potent hypoglycemic effect in this study. It is well known that starch, a polysaccharide, is degraded by amylases to dextrin oligomers; these oligomers are then further degraded to $\alpha$-D-glucoses by $\alpha$-glucosidase. These monomeric may enter the blood circulation via intestinal epithelial absorption. Therefore, the use of $\alpha$-amylase and $\alpha$-glucosidase inhibitors may block or slow down this process, leading to the hypoglycemic effect after meals. Euonymus laxiflorus Champ. condensed tannins (ELC-CT) showed effective inhibition both on $\alpha$-amylase [16] and $\alpha$-glucosidase, since this resulted in their significant hypoglycemic effect. To determine the inhibition mode of ELC-CT, three concentrations of ELC-CT: 0.5, 0.244, $0 \mu \mathrm{g} / \mathrm{mL}$, and $0.05,0.03,0 \mu \mathrm{g} / \mathrm{mL}$ against $\alpha$-amylase, and $\alpha$-glucosidase, respectively, were tested. According to the Lineweaver-Burk plots of enzymatic inhibition kinetics of ELC-CT against $\alpha$-amylase (Figure 4A), and $\alpha$-glucosidase (Figure 4B), ELC-CT was determined as mix (non-competitive-uncompetitive) inhibition against $\alpha$-amylase, and non-competitive inhibition against $\alpha$-glucosidase via comparison to the typical Lineweaver-Burk plots [42].
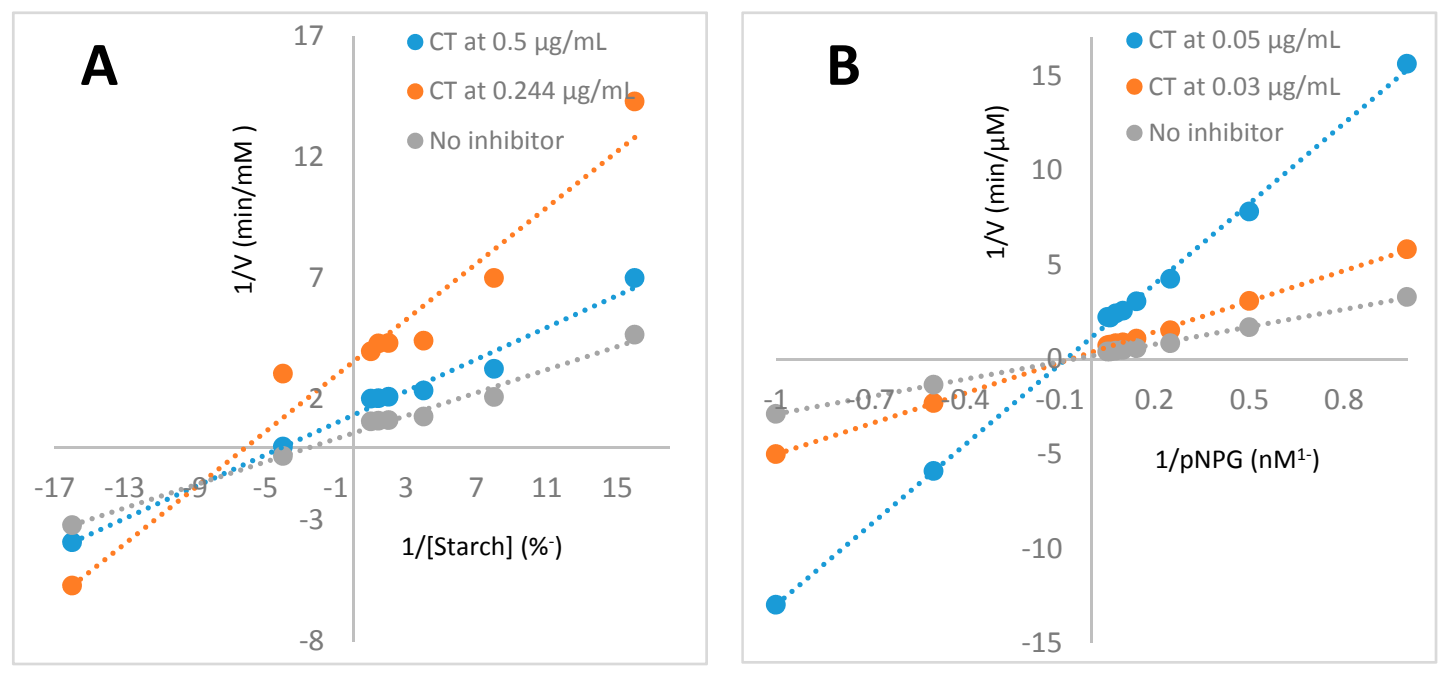

Figure 4. Lineweaver-Burk plots of enzymatic inhibition kinetics of ELC-CT against $\alpha$-amylase (A), and $\alpha$-glucosidase $(\mathbf{B})$.

These results indicated that ELC-CT did not combine with enzymes in the active sites of both enzymes ( $\alpha$-amylase, and $\alpha$-glucosidase); ELC-CT combined with $\alpha$-glucosidase to produce dead-end enzyme-inhibitor complex regardless of the substrate (pNPG) was bound; while some ELC-CT molecules could combine with $\alpha$-amylase-starch complex, but did not combine with free amylase, and some ELC-CT molecules could combine with both $\alpha$-amylase-starch complex, and free amylase to block the amylase activity [42].

According to the results of this study and the previous report [17], suggest that Euonymus laxiflorus Champ. is a rich source of condensed tannins, which could be developed as health food with potent hypoglycemic effect.

\section{Materials and Methods}

\subsection{Materials}

The methanolic extract of Euonymus laxiflorus Champ. trunk bark was obtained from the previous study [4]. Saccharomyces cerevisiae (yeast) $\alpha$-glucosidase and acarbose were purchased from Sigma Chemical Co., St. Louis City, MO, USA; $p$-nitrophenyl glucopyranoside ( $p$ NPG) was obtained from 
Sigma Aldrich, 3050 Spruce Street, St. Louis, MO, USA. All the solvents and common chemicals were obtained at their highest grade.

\subsection{Biological Activity Assays}

\subsection{1. $\alpha$-Glucosidase Inhibitory Activity Determination}

The $\alpha$-glucosidase inhibitory activity was closely detected following the method described in detail by Nguyen et al. (2018) [12]. The mixture of $50 \mu \mathrm{L} \alpha$-glucosidase, $50 \mu \mathrm{L}$ sample solutions, $100 \mu \mathrm{L}$ buffer was pre-incubated at $37^{\circ} \mathrm{C}$ for $20 \mathrm{~min}$; the reaction then started when $50 \mu \mathrm{L}$ of $p$-nitrophenyl glucopyranoside $(10 \mathrm{mmol} / \mathrm{L})$ was added to the mixture. After incubation at the same temperature for $30 \mathrm{~min}$, the reaction was stopped by adding $100 \mu \mathrm{L} \mathrm{Na}_{2} \mathrm{CO}_{3}$ solution $(1 \mathrm{~mol} / \mathrm{L})$ to the reaction mixture; the absorbance of this final mixture was then measured at $410 \mathrm{~nm}$ (A). The control group also underwent the same described method with the use of $50 \mu \mathrm{L}$ buffer instead of $50 \mu \mathrm{L}$ sample solutions; the absorbance was recorded at $410 \mathrm{~nm}(\mathbf{B})$. The aGI activity (\%) was calculated using the following equation:

$$
\mathrm{aGI}(\%)=(\mathrm{A}-\mathrm{B}) / \mathrm{A} \times 100 .
$$

The inhibition was also expressed as $\mathrm{IC}_{50}$ value determined as per the previous study [2]. The enzyme and the samples were prepared in $0.1 \mathrm{~mol} / \mathrm{L}$ potassium phosphate buffer $(\mathrm{pH} 7)$. The purified compounds were tested at concentrations in the range of $0.015-250 \mu \mathrm{g} / \mathrm{mL}$ and the $\mathrm{IC}_{50}$ plots for all tested compounds $(\mathbf{1}, \mathbf{5}, \mathbf{1 0}, \mathbf{1 1}, \mathbf{1 2}, \mathbf{1 4}, \mathbf{1 8}, \mathbf{1 9}$, and 20), and acarbose were presented in the supplementary materials section (Figures S22-S31). The corresponding \% inhibition at each concentration of all tested compounds were also recorded in Figure S32.

\subsubsection{Experimental Animal Protocol}

Animals: seven week-old male ICR (Institute of Cancer Research) mice were purchased from The National Laboratory Animal Center (No. 128, Sec. 2, Academia Rd., Nangang Dist., Taipei City 11529, Taiwan) and tested in accordance with the approval and guidelines of the Institutional Animal Care and Use Committee of the National Research Institute of Chinese Medicine, Ministry of Health and Welfare (IACUC No. 104-706-1, 29 December 2014). Forty ICR mice were randomly divided into 5 groups ( 8 mice/group), including a control group orally administered with distilled water, and 4 experimental groups orally administered with $50 \mathrm{mg} \mathrm{CT} / \mathrm{kg} \mathrm{bw}, 100 \mathrm{mg} \mathrm{CT} / \mathrm{kg}$ bw, $25 \mathrm{mg}$ acarbose $/ \mathrm{kg}$ bw, and $50 \mathrm{mg}$ acarbose $/ \mathrm{kg}$ bw, respectively. Distilled water was used to prepare the condensed tannins and acarbose solutions.

Assay: The effect of condensed tannin-ELCTB-3.1.1 on the reduction of plasma glucose in mice was performed according to the experimental animal protocol described by Nguyen et al. (2017) [11] with the use of starch solution $(3 \mathrm{~g} / \mathrm{kg} \mathrm{bw})$ instead of sucrose solution administered to ICR mice. All the mice groups were fasted overnight $(16 \mathrm{~h})$, and then orally administered water (control group), CT or acarbose (4 experimental groups); thereafter $(20 \mathrm{~min})$ starch solution ( $3 \mathrm{~g} / \mathrm{kg} \mathrm{bw})$ was orally administered to mice; blood was then sampled and measured after $0.5,1.0,1.5$, and $2.0 \mathrm{~h}$.

\subsubsection{Determination of Enzymatic Inhibition Modes of Isolated Condensed Tannin}

The inhibition mode of condensed tannin was determined by performing as the reported assay with minor modification [10]. Enzyme kinetics of the isolated condensed tannin was determined using the $\alpha$-glucosidase and $\alpha$-amylase inhibitory activity assay mentioned above. The concentration range used was $2-18 \mathrm{mmol} / \mathrm{L}$ pNPG, and $0.0625-2 \%$ starch for the $\alpha$-glucosidase, and $\alpha$-amylase inhibitory activity assays, respectively. The inhibition modes of the sample were determined by analyzing the Vmax and comparing the Lineweaver-Bur plots of condensed tannin to the standard typical Lineweaver-Bur plots [42]. 


\subsection{Purification and Identification Procedures of the Active aGIs}

Methanolic extract of ELCTB (40 g) was primarily fractionated via a Diaion column with successive eluting with distilled water, $40 \% \mathrm{MeOH}, 70 \% \mathrm{MeOH}, 100 \% \mathrm{MeOH}$, and $100 \%$ ethyl acetate to obtain 5 fractions: ELCTB-1 (20.97 g), ELCTB-2 (9.12 g), ELCTB-3 (4.67 g), ELCTB-4 (1.46 g), ELCTB-5 (1.63 g), respectively.

ELCTB-2 (4.5 g) was loaded onto an ODS column and 10 subfractions were obtained with the elution of a gradient mobile phase of $\mathrm{MeOH}$ in $\mathrm{H}_{2} \mathrm{O}(0-100 \%, v / v)$. The 3 subfractions: ELCTB-2.1 $(1.8 \mathrm{~g})$, ELCTB-2.2 (0.5 g), and ELCTB-2.3 (0.25 g) were obtained by eluting with $\%$, 5\%, and $10 \% \mathrm{MeOH}$ in $\mathrm{H}_{2} \mathrm{O}$, respectively. All of these subfractions were further separated by injecting them into a preparative HPLC (Pr-HPLC) (preparative Cosmosil 5C18-AR-II column equipped with a $250 \times 20 \mathrm{~mm}$ i.d. and a UV detector (Nacalai Tesque, Inc., Kyoto, Japan) at 210 and $254 \mathrm{~nm}$ ) for the isolation of 17 compounds (1-17) via elution with $8 \% \mathrm{ACN}$ (compounds 1-5), 5\% ACN (compounds 5-17).

ELCTB-3 ( $4.5 \mathrm{~g}$ ) was also loaded onto the same ODS column and then eluted by ACN in the $\mathrm{H}_{2} \mathrm{O}$ mobile phase with the gradient of 10-100\%, $v / v$, to obtain 10 subfractions (ELCTB-3.1-ELCTB-3.10). Two subfractions: ELCTB-3.1 (1.8 g), and ELCTB-3.3 (0.6 g) were collected by eluting with 10\% and 20\% ACN, respectively. ELCTB-3.3 (0.6 g) was further separated via the same column and eluted with ACN in $\mathrm{H}_{2} \mathrm{O}$ mobile phase with a gradient of 0-100\%, $v / v$, and 10 subfractions (ELCTB-3.3.1-ELCTB-3.3.10) were obtained. Of these, 3 subfractions: ELCTB-3.3.4, ELCTB-3.3.5, and ELCTB-3.3.6, eluted with $10 \%, 13 \%$, and $16 \% \mathrm{ACN}$, respectively, were injected into the Pr-HPLC for the isolation of 8 compounds (19-26) by the elution with $14 \%$ ACN $(19,20,25,26)$, and 22\% MeOH (21-24). Compound 18 was obtained from subfraction ELCTB-3.1 via dialysis. The purification process is summarized in Figure 1.

The chemical structures of the isolated compounds were identified via analysis of their NMR data, coupled with the comparison of those of reported compounds. The ${ }^{1} \mathrm{H}$ and ${ }^{13} \mathrm{C}-\mathrm{NMR}$ spectra, and 2D-NMR spectra (COSY, HMQC, HMBC, and NOESY), were recorded in $\mathrm{MeOH}-d_{4}$ on a Bruker AVX NMR spectrometer (Bruker, Karlsruhe, Germany) operating at $600 \mathrm{MHz}$ for 1 to $12 \mathrm{~h}$ and $150 \mathrm{MHz}$ for ${ }^{13} \mathrm{C}$ using the $\mathrm{MeOH}-d_{4}$ solvent peak as internal standard $\left(\delta_{\mathrm{H}} 3.317, \delta_{\mathrm{C}} 49.1 \mathrm{ppm}\right)$.

\subsection{Characteristics and NMR Data of Identified Compounds}

Compound 1: Walterolactone $A / B \beta$-D-pyranoglucoside was obtained as a white amorphous powder. ${ }^{1} \mathrm{H}-\mathrm{NMR}$ data $\left(600 \mathrm{MHz}, \mathrm{MeOH}-d_{4}, \delta_{\mathrm{H}} \mathrm{ppm}\right): 5.86(\mathrm{q}, J=1.8 \mathrm{~Hz}), 4.57(\mathrm{dd}, J=12.0,3.0 \mathrm{~Hz}), 4.42(\mathrm{dd}$, $J=12.0,3.0 \mathrm{~Hz}), 4.41(\mathrm{~d}, J=7.8 \mathrm{~Hz}), 4.40(\mathrm{t}, J=3.0 \mathrm{~Hz}), 3.88(\mathrm{dd}, J=12.0,1.8 \mathrm{~Hz}), 3.67(\mathrm{dd}, J=12.0$, $5.4 \mathrm{~Hz}), 3.36(\mathrm{t}, J=9.0 \mathrm{~Hz}), 3.29(\mathrm{~m}, 2 \mathrm{H}), 3.17(\mathrm{dd}, J=9.0,7.8 \mathrm{~Hz}), 2.10(\mathrm{~d}, J=1.8 \mathrm{~Hz}) .{ }^{13} \mathrm{C}-\mathrm{NMR}$ data (150 MHz, MeOH- $d_{4}, \delta_{\mathrm{C}}$ ppm): 166.1, 158.6, 118.9, 103.0, 78.2, 78.0, 74.8, 71.5, 71.0, 70.3, 62.7, 20.4.

Compound 9: 1- $\beta$-D-glucopyranosyloxy-3,5-dimethoxy-4-hydroxybenzene was obtained as a white amorphous powder. ${ }^{1} \mathrm{H}-\mathrm{NMR}$ data $\left(600 \mathrm{MHz}, \mathrm{MeOH}-d_{4}, \delta_{\mathrm{H}} \mathrm{ppm}\right): 6.5(\mathrm{~s}, 2 \mathrm{H}), 4.75(\mathrm{~d}, J=7.2 \mathrm{~Hz}), 3.91$ $(\mathrm{dd}, J=12.0,2.4 \mathrm{~Hz}), 3.81(\mathrm{~s}, 6 \mathrm{H}), 3.66(\mathrm{dd}, J=12.0,6.6 \mathrm{~Hz}), 3.4 \sim 3.5(\mathrm{~m}, 3 \mathrm{H}) .{ }^{13} \mathrm{C}-\mathrm{NMR}$ data $(150 \mathrm{MHz}$, $\left.\mathrm{MeOH}-d_{4}, \delta_{\mathrm{C}} \mathrm{ppm}\right): 152.4,149.4,131.0,103.8,96.6,78.2,77.9,74.9,62.7$ and 56.8.

Compound 10: (-)-Gallocatechin was obtained as a white amorphous powder. ${ }^{1} \mathrm{H}-\mathrm{NMR}$ data $(600 \mathrm{MHz}$, MeOH- $\left.d_{4}, \delta_{\mathrm{H}} \mathrm{ppm}\right): 6.40(\mathrm{~s}, 2 \mathrm{H}), 5.92(\mathrm{~d}, J=2.4 \mathrm{~Hz}), 5.85(\mathrm{~d}, J=2.4 \mathrm{~Hz}), 4.52(\mathrm{~d}, J=7.2 \mathrm{~Hz}), 3.96(\mathrm{~m})$, $2.8(\mathrm{dd}, J=15.6,5.4 \mathrm{~Hz}), 2.49(\mathrm{dd}, J=15.6,7.8 \mathrm{~Hz}) .{ }^{13} \mathrm{C}-\mathrm{NMR}$ data $\left(150 \mathrm{MHz}, \mathrm{MeOH}-d_{4}, \delta_{\mathrm{C}} \mathrm{ppm}\right)$ : $157.8,157.6,156.8,146.9,134.0,131.5,107.2,100.8,96.3,95.5,82.9,68.7,28.1$.

Compound 11: Schweinfurthinol 9-O- $\beta$-D-pyranoglucoside or 1-(4-hydroxyphenyl)-2,3-dihydroxypropan-1-one 3-O- $\beta$-D-pyranoglucoside was obtained as a white amorphous powder. ${ }^{1} \mathrm{H}-\mathrm{NMR}$ data $\left(600 \mathrm{MHz}, \mathrm{MeOH}-d_{4}\right.$, $\left.\delta_{\mathrm{H}} \mathrm{ppm}\right): 7.93(\mathrm{~d}, J=7.2 \mathrm{~Hz}, 2 \mathrm{H}), 6.85(\mathrm{~d}, J=7.2 \mathrm{~Hz}, 2 \mathrm{H}), 5.28(\mathrm{dd}, J=6.6,3.6 \mathrm{~Hz}), 4.25(\mathrm{~d}, J=7.8 \mathrm{~Hz}), 4.18$ $(\mathrm{dd}, J=11.4,3.6 \mathrm{~Hz}), 3.84(\mathrm{dd}, J=12.0,1.8 \mathrm{~Hz}), 3.73(\mathrm{dd}, J=11.4,6.6 \mathrm{~Hz}), 3.65(\mathrm{dd}, J=12.0,6.0 \mathrm{~Hz}), 3.32$ (overlapped), $3.28(\mathrm{t}, J=9.0 \mathrm{~Hz}), 3.26(\mathrm{~m}), 3.19(\mathrm{dd}, J=9.0,7.2 \mathrm{~Hz}) .{ }^{13} \mathrm{C}-\mathrm{NMR}$ data $\left(150 \mathrm{MHz}, \mathrm{MeOH}-d_{4}\right.$, $\delta_{\mathrm{C}}$ ppm): 198.6, 162.8, 132.5, 127.5, 116.6, 105.0, 78.0, 77.8, 75.1, 74.3, 73.8, 71.5, 62.6. 
Compound 12: 1-O-(3-methyl)-butenoyl-myo-inositol or Myo-inositol 1-O-3,3-dimethylacrylate was obtained as a white amorphous powder. ${ }^{1} \mathrm{H}-\mathrm{NMR}$ data $\left(600 \mathrm{MHz}, \mathrm{MeOH}-d_{4}, \delta_{\mathrm{H}} \mathrm{ppm}\right): 5.81$ (brs), 4.62 (dd, $J=10.2,2.4 \mathrm{~Hz}), 4.05(\mathrm{t}, J=2.4 \mathrm{~Hz}), 3.82(\mathrm{dd}, J=10.2,9.6 \mathrm{~Hz}), 3.63(\mathrm{t}, J=9.0 \mathrm{~Hz}), 3.41(\mathrm{dd}, J=9.0$, $2.4 \mathrm{~Hz}), 3.22(\mathrm{dd}, J=9.6,9.0 \mathrm{~Hz}), 2.16(\mathrm{~d}, J=1.2 \mathrm{~Hz}), 1.92(\mathrm{~d}, J=1.2 \mathrm{~Hz}) .{ }^{13} \mathrm{C}-\mathrm{NMR}$ data $(150 \mathrm{MHz}$, $\left.\mathrm{MeOH}-d_{4}, \delta_{\mathrm{C}} \mathrm{ppm}\right): 167.7,158.7,117.0,76.6,75.0,74.1,73.1,72.0,71.8,27.4,20.4$.

Compound 14: Leonuriside was obtained as a white amorphous powder. ${ }^{1} \mathrm{H}-\mathrm{NMR}$ data $(600 \mathrm{MHz}$, $\left.\mathrm{MeOH}-d_{4}, \delta_{\mathrm{H}} \mathrm{ppm}\right): 6.13(\mathrm{~s}, 2 \mathrm{H}), 4.66(\mathrm{~d}, J=7.2 \mathrm{~Hz}), 3.79(\mathrm{~s}, 6 \mathrm{H}), 3.78(\mathrm{dd}, J=12.0,2.4 \mathrm{~Hz}), 3.67(\mathrm{dd}$, $J=12.0,5.4 \mathrm{~Hz}), 3.4 \sim 3.5(\mathrm{~m}, 2 \mathrm{H}), 3.36$ (overlapped), $3.19(\mathrm{~m}) .13 \mathrm{C}-\mathrm{NMR}$ data $(150 \mathrm{MHz}, \mathrm{MeOH}-\mathrm{d} 4, \delta \mathrm{C}$ ppm): 155.9, 154.7, 129.6, 94.5, 106.1, 78.2, 77.7, 75.7, 65.2 and 56.8.

Compounds $5 \mathcal{E}$ 18: condensed tannins were obtained as brow yellow amorphous powder: ${ }^{13} \mathrm{C}-\mathrm{NMR}$ data $\left(150 \mathrm{MHz}, \mathrm{MeOH}-d_{4}, \delta_{\mathrm{C}} \mathrm{ppm}\right):$ 161.0, 155.0, 144.5, 138.5, 132.0, 122.0-118.0, 116.3-114.0, 107.0, $102.0,97.0,76.0,35.5$ and 34.0).

Compound 19 (+)-Catechin was obtained as a white amorphous powder. ${ }^{1} \mathrm{H}-\mathrm{NMR}$ data $(600 \mathrm{MHz}$, $\left.\mathrm{MeOH}-d_{4}, \delta_{\mathrm{H}} \mathrm{ppm}\right): 6.83(\mathrm{~d}, J=1.8 \mathrm{~Hz}), 6.76(\mathrm{~d}, J=7.8 \mathrm{~Hz}), 6.71(\mathrm{dd}, J=7.8,1.8 \mathrm{~Hz}), 5.93(\mathrm{~d}, J=2.4 \mathrm{~Hz})$, $5.85(\mathrm{~d}, J=2.4 \mathrm{~Hz}), 4.46(\mathrm{~d}, J=7.8 \mathrm{~Hz}), 3.98(\mathrm{~m}), 2.83(\mathrm{dd}, J=16.2,5.4 \mathrm{~Hz}), 2.49(\mathrm{dd}, J=16.2,8.4 \mathrm{~Hz})$. ${ }^{13} \mathrm{C}-\mathrm{NMR}$ data $\left(150 \mathrm{MHz}, \mathrm{MeOH}-d_{4}, \delta_{\mathrm{C}} \mathrm{ppm}\right): 157.7,157.5,156.8,146.2,132.2,120.1,116.2,115.3,100.9$, $96.3,95.5,82.8,68.7,28.5$.

Compound 20: Methyl galloate was obtained as a white amorphous powder. ${ }^{1} \mathrm{H}-\mathrm{NMR}$ data $(600 \mathrm{MHz}$, $\left.\mathrm{MeOH}-d_{4}, \delta_{\mathrm{H}} \mathrm{ppm}\right): 7.05(\mathrm{~s}, 2 \mathrm{H}), 3.72(\mathrm{~s}, 3 \mathrm{H}) .{ }^{13} \mathrm{C}-\mathrm{NMR}$ data $\left(150 \mathrm{MHz}, \mathrm{MeOH}-d_{4}, \delta_{\mathrm{C}} \mathrm{ppm}\right): 167.7$, $145.9,138.8,121.0,109.5,52.0$.

Compound 23: (-)-Catechin was obtained as a white amorphous powder. ${ }^{1} \mathrm{H}-\mathrm{NMR}$ data $(600 \mathrm{MHz}$, $\left.\mathrm{MeOH}-d_{4}, \delta_{\mathrm{H}} \mathrm{ppm}\right): 6.83(\mathrm{~d}, J=1.8 \mathrm{~Hz}), 6.76(\mathrm{~d}, J=7.8 \mathrm{~Hz}), 6.71(\mathrm{dd}, J=7.8,1.8 \mathrm{~Hz}), 5.93(\mathrm{~d}, J=2.4 \mathrm{~Hz})$, $5.85(\mathrm{~d}, J=2.4 \mathrm{~Hz}), 4.46(\mathrm{~d}, J=7.8 \mathrm{~Hz}), 3.98(\mathrm{~m}), 2.83(\mathrm{dd}, J=16.2,5.4 \mathrm{~Hz}), 2.49(\mathrm{dd}, J=16.2,8.4 \mathrm{~Hz})$. ${ }^{13} \mathrm{C}-\mathrm{NMR}$ data $\left(150 \mathrm{MHz}, \mathrm{MeOH}-d_{4}, \delta_{\mathrm{C}} \mathrm{ppm}\right): 157.7,157.5,156.8,146.2,132.2,120.1,116.2,115.3,100.9$, $96.3,95.5,82.8,68.7,28.5$.

\subsection{Statistical Analysis}

Statistical Analysis Software (SAS) version 9.4, provided by SAS Institute Taiwan Ltd., Minsheng East Road, Section 2, Taipei, Taiwan 149-8, was used to analyze the differences between the means of inhibition, and blood glucose level via Duncan's Multiple Range Test (alpha $=0.01$ or 0.05 ). All tests were repeated in triplicate.

\section{Conclusions}

Eleven hypoglycemic compounds were isolated and identified from the methanolic extract of Euonymus laxiflorus Champ. trunk bark. Of these, four novel compounds of walterolactone A/B $\beta$-D-pyranoglucoside (1), schweinfurthinol 9-O- $\beta$-D-pyranoglucoside (11), 1-O-(3-methyl)-butenoyl-myo-inositol (12), and leonuriside (14) were determined as new $\alpha$-glucosidase inhibitors. The results of in vitro tests indicated that most of the isolated compounds $(\mathbf{1}, \mathbf{5}, \mathbf{1 0}-\mathbf{1 2}$, 17, and 18) showed much higher activity than that of acarbose. Codensed tannin (18) demonstrated significant reduction of blood glucose in mice at the dose of $100 \mathrm{mg} / \mathrm{kg}$ bw. The results could enrich the current biological activities of constituents isolated from Euonymus laxiflorus Champ. species, and also suggest that this medicinal plant is a valuable source of bioactive compounds for development as health food or drugs with potent hypoglycemic effect.

Supplementary Materials: The following are available online, including 32 figures (Figure S1-S32).

Author Contributions: Conceived the study: S.-L.W., V.B.N. and A.D.N. Designed the study: V.B.N., S.-L.W., A.D.N. and T.H.N. Performed the experiments: V.B.N., T.H.N., M.T.N., Z.-H.L., C.T.D., T.N.T. and Q.V.N. Contributed reagents/materials/analysis tools: S.-L.W., A.D.N., Y.-H.K. and V.B.N. Analyzed data and wrote the paper: V.B.N. and S.L.W. 
Funding: This research received no external funding.

Acknowledgments: This work was supported in part by a grant from the Ministry of Science and Technology, Taiwan (MOST 106-2320-B-032-001-MY3), Ministry of Education, Taiwan (TKU 0657010), the Ministry of Science and Technology, Taiwan (MOST104-2320-B-077-006-MY3), and Ministry of Health and Welfare, Taiwan (MOHW107-NRICM-B-315-143002), Ministry of Science and Technology, Vietnam (MOST. NVQG-2018/19).

Conflicts of Interest: The authors declare no conflict of interest.

\section{References}

1. Nguyen, V.B.; Nguyen, T.H.; Doan, C.T.; Tran, T.N.; Nguyen, A.D.; Kuo, Y.H.; Wang, S.L. Production and bioactivity-guided isolation of antioxidants with $\alpha$-glucosidase inhibitory and anti-NO properties from marine chitinous materials. Molecules 2018, 23, 1124. [CrossRef] [PubMed]

2. Nguyen, V.B.; Nguyen, A.D.; Wang, S.L. Utilization of fishery processing by-product squid pens for $\alpha$-glucosidase inhibitors production by Paenibacillus sp. Mar. Drugs 2017, 15, 274. [CrossRef] [PubMed]

3. DeMelo, E.B.; Gomes, A.; Carvalha, I. $\alpha$-and $\beta$-Glucosidase inhibitors: Chemical structure and biological activity. J. Tetrahedr. 2006, 62, 10277-10302.

4. Nguyen, V.B.; Nguyen, Q.V.; Nguyen, A.D.; Wang, S.L. Screening and evaluation of $\alpha$-glucosidase inhibitors from indigenous medicinal plants in Dak Lak Province, Vietnam. Res. Chem. Intermed. 2017, 43, 3599-3612. [CrossRef]

5. Nguyen, Q.V.; Nguyen, V.B.; Eun, J.B.; Wang, S.L.; Nguyen, D.H.; Tran, T.N.; Nguyen, A.D. Anti-oxidant and antidiabetic effect of some medicinal plants belong to Terminalia species collected in Dak Lak Province, Vietnam. Res. Chem. Intermed. 2016, 42, 5859-5871. [CrossRef]

6. Nguyen, Q.V.; Wang, S.L.; Nguyen, A.D. In vitro $\alpha$-glucosidase and $\alpha$-amylase inhibition, and in vivo anti-hyperglycemic effects of Psidium littorale Raddi leaf extract. Res. Chem. Intermed. 2018, 44, 1745-1753. [CrossRef]

7. Nguyen, V.B.; Wang, S.-L.; Nhan, N.T.; Nguyen, T.H.; Nguyen, N.P.D.; Nghi, D.H.; Cuong, N.M. New records of potent in-vitro antidiabetic properties of Dalbergia tonkinensis heartwood and the bioactivity-guided isolation of active compounds. Molecules 2018, 23, 1589. [CrossRef] [PubMed]

8. Nguyen, V.B.; Wang, S.L. Reclamation of marine chitinous materials for the production of $\alpha$-glucosidase inhibitors via microbial conversion. Mar. Drugs 2017, 15, 350. [CrossRef] [PubMed]

9. Wang, S.L.; Su, Y.C.; Nguyen, V.B.; Nguyen, A.D. Reclamation of shrimp heads for the production of $\alpha$-glucosidase inhibitors by Staphylococcus sp. TKU043. Res. Chem. Intermed. 2018, 44, 4929-4937. [CrossRef]

10. Hsu, C.H.; Nguyen, V.B.; Nguyen, A.D.; Wang, S.L. Conversion of shrimp heads to $\alpha$-glucosidase inhibitors via co-culture of Bacillus mycoides TKU040 and Rhizobium sp. TKU041. Res. Chem. Intermed. 2017, 44, 4597-4607. [CrossRef]

11. Nguyen, V.B.; Nguyen, A.D.; Kuo, Y.H.; Wang, S.L. Biosynthesis of $\alpha$-glucosidase inhibitors by a newly isolated bacterium, Paenibacillus sp. TKU042 and its effect on reducing plasma glucose in mouse model. Int. J. Mol. Sci. 2017, 18, 700. [CrossRef] [PubMed]

12. Nguyen, V.B.; Wang, S.L. New novel $\alpha$-glucosidase inhibitors produced by microbial conversion. Process Biochem. 2018, 65, 228-232. [CrossRef]

13. Wang, G.; Peng, Z.; Wang, J.; Li, X.; Li, J. Synthesis, in vitro evaluation and molecular docking studies of novel triazine-triazole derivatives as potential $\alpha$-glucosidase inhibitors. Eur. J. Med. Chem. 2017, 125, 423-429. [CrossRef] [PubMed]

14. Ghani, U. Re-exploring promising a-glucosidase inhibitors for potential development into oral anti-diabetic drugs: Finding needle in the haystack. Eur. J. Med. Chem. 2015, 103, 133-162. [CrossRef] [PubMed]

15. Flora of China. Available online: http://www.efloras.org/florataxon.aspx?flora_id=2\&taxon_id=200012808 (accessed on 10 May 2018).

16. Nguyen, V.B.; Nguyen, Q.V.; Nguyen, A.D.; Wang, S.L. Porcine pancreatic $\alpha$-amylase inhibitors from Euonymus laxiflorus Champ. Res. Chem. Intermed. 2017, 43, 259-269. [CrossRef]

17. Nguyen, Q.V.; Nguyen, N.H.; Wang, S.L.; Nguyen, V.B.; Nguyen, A.D. Free radical scavenging and antidiabetic activities of Euonymus laxiflorus champ extract. Res. Chem. Intermed. 2017, 43, 5615-5624. [CrossRef] 
18. Nguyen, V.B.; Wang, S.L.; Nguyen, A.D.; Vo, T.P.K.; Zhang, L.J.; Nguyen, Q.V.; Kuo, Y.H. Isolation and identification of novel $\alpha$-amylase inhibitors from Euonymus laxiflorus Champ. Res. Chem. Intermed. 2018, 44, 1411-1424. [CrossRef]

19. Liu, L.M.; Cheng, S.F.; Shieh, P.C.; Lee, J.C.; Chen, J.J.; Ho, C.T.; Kuo, S.C.; Kuo, D.H.; Huang, L.J.; Way, T.D. The methanol extract of Euonymus laxiflorus, Rubia lanceolata and Gardenia jasminoides inhibits xanthine oxidase and reduce serum uric acid level in rats. Food Chem. Toxicol. 2014, 70, 179-184. [CrossRef] [PubMed]

20. Shao, J.H.; Chen, J.; Zhao, C.C.; Shen, J.; Liu, W.Y.; Gu, W.Y.; Li, K.H. Insecticidal and $\alpha$-glucosidase inhibitory activities of chemical constituents from Viburnum fordiae Hance. Nat. Prod. Res. 2018, 27, 1-6. [CrossRef] [PubMed]

21. Nomizu, K.; Hashida, K.; Makino, R.; Ohara, S. Antioxidants from steamed used tea leaves and their reaction behavior. Biosci. Biotechnol. Biochem. 2008, 72, 1682-1689. [CrossRef] [PubMed]

22. Shrestha, S.; Lee, D.Y.; Park, J.H.; Cho, J.G.; Lee, D.S.; Li, B.; Kim, Y.C.; Kim, G.; Bang, M.H.; Baek, N.I. Phenolic components from Rhus parviflora fruits and their inhibitory effects on lipopolysaccharide-induced nitric oxide production in RAW 264.7 macrophages. Nat. Prod. Res. 2013, 27, 2244-2247. [CrossRef] [PubMed]

23. Li, X.; Liu, Z.; Zhang, X.F.; Wang, L.J.; Zheng, Y.N.; Yuan, C.C.; Sun, G.Z. Isolation and characterization of phenolic compounds from the leaves of Salix matsudana. Molecules 2008, 13, 1530-1537. [CrossRef] [PubMed]

24. Guo, P.; Anderson, J.D.; Bozell, J.J.; Zivanovic, S. The effect of solvent composition on grafting gallic acid onto chitosan via carbodiimid. Carbohydr. Polym. 2016, 140, 171-180. [CrossRef] [PubMed]

25. Schofield, P.; Mbugua, D.M.; Pell, A.N. Analysis of condensed tannins: A review. Anim. Feed. Sci. Technol. 2001, 91, 21-40. [CrossRef]

26. Li, C.; Leverence, R.; Trombley, J.D.; Xu, S.; Yang, J.; Tian, Y.; Reed, J.D.; Hagerman, A.E. High molecular weight persimmon (Diospyros kaki) proanthocyanidin: A highly galloylated, a-linked tannin with an unusual flavonol terminal unit, myricetin. J. Agric. Food Chem. 2010, 58, 9033-9042. [CrossRef] [PubMed]

27. Chai, W.M.; Shi, Y.; Feng, H.L.; Qiu, L.; Zhou, H.C.; Deng, Z.W.; Yan, C.L.; Chen, Q.X. NMR, HPLC-ESI-MS, and MALDI-TOF MS analysis of condensed tannins from Delonix regia (Bojer ex Hook.) Raf. and their bioactivities. J. Agric. Food Chem. 2012, 60, 5013-5022. [CrossRef] [PubMed]

28. Sadik, G.; Islam, R.; Rahman, M.M.; Khondkar, P.; Rashid, M.A.; Sarker, S.D. Antimicrobial and cytotoxic constituents of Loranthus globosus. Fitoterapia 2003, 74, 308-311. [CrossRef]

29. Kwon, D.H.; Choi, W.J.; Lee, C.H.; Kim, J.H.; Kim, M.B. Flavonoid Compound Having an Antiviral Activity. U.S. Patent 7,998,937, 16 August 2011.

30. Lianda, R.L.P.; Santana, L.D.; Echevarria, A.; Castro, R.N. Polyphenolic compounds in the fruits of Egyptian medicinal plants (Terminalia bellerica, Terminalia chebula and Terminalia horrida): Characterization, quantitation and determination of antioxidant capacities. J. Braz. Chem. Soc. 2012, 23, 618-627.

31. Jing, H.; Xing, Y.F.; Huang, B.; Zhang, Y.Z.; Zeng, C.M. Tea catechins induce the conversion of preformed lysozyme amyloid fibrils to amorphous aggregates. J. Agric. Food Chem. 2009, 57, 11391-11396.

32. Ngoumfo, R.M.; Ngounou, G.E.; Tchamadeu, C.V.; Qadir, M.I.; Mbazoa, C.D.; Begum, A.; Ngninzeko, F.N.; Lontsi, D.; Choudhary, M.I. Inhibitory effect of macabarterin, a polyoxygenated ellagitannin from Macaranga barteri, on human neutrophil respiratory burst activity. J. Nat. Prod. 2008, 71, 1906-1910. [CrossRef] [PubMed]

33. Rawat, P.; Khan, M.F.; Kumar, M.; Tamarkar, A.K.; Srivastava, A.K.; Arya, K.R.; Maurya, R. Constituents from fruits of Cupressus sempervirens. Fitoterapia 2010, 81, 162-166. [CrossRef] [PubMed]

34. Zhao, J.; Zhou, X.W.; Chen, X.B.; Wang, Q.X. $\alpha$-Glucosidase inhibitory constituents from Toona sinensis. Chem. Nat. Compd. 2009, 45, 244-246. [CrossRef]

35. Sanae, F.; Miyaichi, Y.; Kizu, H.; Hayashi, H. Effects of catechins on vascular tone in rat thoracic aorta with endothelium. Life Sci. 2002, 71, 2553-2562. [CrossRef]

36. Yusoff, N.A.; Ahmad, M.; al Hindi, B.; Widyawati, T.; Yam, M.F.; Mahmud, R.; Razak, K.N.A.; Asmawi, M.Z. Aqueous extract of Nypa fruticans wurmb. Vinegar alleviates postprandial hyperglycemia in normoglycemic rats. Nutrients 2015, 7, 7012-7026. [CrossRef] [PubMed]

37. Bryans, J.A.; Judd, P.A.; Ellis, P.R. The effect of consuming instant black tea on postprandial plasma glucose and insulin concentrations in healthy humans. J. Am. Coll. Nutr. 2007, 26, 471-478. [CrossRef] [PubMed]

38. Igarashi, M.; Satoh, T.; Yamashita, H.; Wantanabe, K. Black tea inhibits small intestinal $\alpha$-glucosidase activity in $\mathrm{db} / \mathrm{db}$ mouse. Jpn. J. Complem. Altern. Med. 2014, 11, 25-33. [CrossRef] 
39. da Silva, S.M.; Koehnlein, E.A.; Bracht, A.; Castoldi, R.; de Morais, G.R.; Baesso, M.L.; Peralta, R.A.; de Souza, C.G.M.; de Sa-Nakanishi, A.B.; Peralta, R.M. Inhibition of salivary and pancreatic $\alpha$-amylases by a pinhão coat (Araucaria angustifolia) extract rich in condensed tannin. Food Res. Int. 2014, 56, 1-8. [CrossRef]

40. Ogawa, S.; Yazaki, Y. Tannins from acacia mearnsii de wild. bark: Tannin determination and biological activities. Molecules 2018, 23, 837. [CrossRef] [PubMed]

41. Kumari, M.; Jain, S. Tannins: An antinutrient with positive effect to manage diabetes. Res. J. Recent Sci. 2012, 1, 70-73.

42. Palmer, T. Understanding Enzymes, 3rd ed.; Ellis Horwood Limited: Chichester, UK, 1991; p. 155.

Sample Availability: Samples of the compounds including Walterolactone A/B $\beta$-D-pyranoglucoside, and condensed tannin-ELCTB-3.1 (compound 18) isolated from ELCTB extract are available from the authors.

(c) 2018 by the authors. Licensee MDPI, Basel, Switzerland. This article is an open access article distributed under the terms and conditions of the Creative Commons Attribution (CC BY) license (http:/ / creativecommons.org/licenses/by/4.0/). 